\title{
Relationship between Symptoms, Use of PPE and Habits Related to Occupational Exposure to BTEX Compounds in Workers of Gas Stations in Bahia, Brazil
}

\author{
Lidmary P. Alves' ${ }^{1}$ Daniela S. P. Vieira', Luís Sérgio S. Nunes' ${ }^{1}$, Lícia P. S. Cruz ${ }^{2}$, \\ Ana Caroline S. Reis ${ }^{1}$, Ícaro V. S. Gomes ${ }^{2}$, Sâmeque R. Luz ${ }^{2}$, Akácia V. S. Santos ${ }^{2}$, \\ Mabel B. Esteves ${ }^{*}$
}

\begin{abstract}
${ }^{1}$ Center of Biomedical Research, Professional Masters in Bioenergy, College of Technology and Science-FTC, Salvador, Brazil
${ }^{2}$ Analytical Chemistry Department, Chemistry Institute, Federal University of Bahia-UFBA, Salvador, Brazil

Email: *mabel.esteves@gmail.com
\end{abstract}

How to cite this paper: Alves, L.P., Vieira, D.S.P., Nunes, L.S.S., Cruz, L.P.S., Reis, A.C.S., Gomes, Í.V.S., Luz, S.R., Santos, A.V.S. and Esteves, M.B. (2017) Relationship between Symptoms, Use of PPE and Habits Related to Occupational Exposure to BTEX Compounds in Workers of Gas Stations in Bahia, Brazil. Journal of Environmental Protection, 8, 650-661. https://doi.org/10.4236/jep.2017.85042

Received: April 4, 2017

Accepted: May 24, 2017

Published: May 27, 2017

Copyright (c) 2017 by authors and Scientific Research Publishing Inc. This work is licensed under the Creative Commons Attribution International License (CC BY 4.0).

http://creativecommons.org/licenses/by/4.0/

\begin{abstract}
To show the risks and harm caused by the occupational exposure to the benzene, toluene, ethylbenzene and xylenes compounds (BTEX), the working conditions of 113 persons employed at gas stations in the cities of Riachão do Jacuipe, Feira de Santana and Salvador in the state of Bahia, Brazil were investigated by experts who correlated protection measures required by law and those applied to the workers. Data collection was performed by help of a questionnaire and non-participant observation record. The age groups of the workers in the three cities surveyed were between 18 to 25 years $(30.08 \%)$ and 26 to 33 years $(34.51 \%)$ of the total. The study revealed an association between occupational habits of workers at gas stations and the prevalence of symptoms due to the exposure to the BTEX compounds. Regarding the use of Personal Protective Equipment (PPE) most workers wear boots. The data show that these workers reported symptoms such as headache, rhinitis, leg pain, drowsiness, cough, fatigue, insomnia, tremors and palpitations. These disorders are related back to previous exposure to BTEX compounds which is associated with inadequate occupational habits of the workers which potentiate chemical contamination in their respective environment.
\end{abstract}

\section{Keywords}

BTEX, Gas Stations, Occupational Exposure, Symptoms 


\section{Introduction}

Most of the energy consumed on the planet originates from fossil fuels such as oil, coal and natural gas. All of them are non-renewable and limited energy sources. The urbanization, the population growth, the development of new technologies and the significantly increasing fleet of motor vehicles are responsible for continuously raising the emission rates of atmosphere pollutants [1] [2] [3].

Due to their toxicity and carcinogenic potential the volatile organic compounds cause hazardous effects on human health. Among the monoaromatic volatile organic compounds, we can highlight benzene and its derivatives such ethylbenzene, toluene and xylenes, also known as BTEX [3]. Globally, about two million workers are estimated to be exposed to benzene annually. This compound is not only carcinogenic, but also the fifth dangerous substance to human health according to United Nations Chemical Safety Program [4].

Studies have shown that workers exposed to gasoline vapors for periods of 8 9 hours daily constitute a vulnerable public [5] [6]. During the process of refueling cars with fuel, the workers inhale gasoline vapors and can also expose their hands and arms increasing contact with BTEX compounds. The carcinogenic potential of benzene to man was rated by the International Agency for Research on Cancer (IARC) [7]. The absorption of benzene occurs primarily by inhalation of the compound in gaseous form and secondarily, via the skin, through contact with its liquid form, in addition to oral absorption [8].

The risks of occupational exposure to BTEX compounds have been shown in several epidemiological studies, which suggests that individuals working at gas stations experience numerous symptoms such as chronic respiratory diseases, decreased lung function, rhinitis, headache, increased propensity to asthma and peripheral hematological alterations, such as anemia, leucopenia, lymphocytopenia and thrombocytopenia [9] [10].

Constant exposure to BTEX compounds can cause eye, mucosal and skin irritation, central nervous system deficiency, bone marrow depletion and cancer. Symptoms such as gastrointestinal compromise with more frequent stomach pain, heartburn and indigestion having been also reported. Besides, the epidermis/dermis can be affected, so that allergies and pruritus can afflict mainly the hands. The respiratory system can also be injured [11].

According to the National Cancer Institute (INCA) environmental exposure to compounds BTEX in Brazil is responsible for the comparatively high cancer rate in this country [12]. The World Health Organization (WHO) recommends standards for the control of benzene exposure both through systematic and continuous monitoring in working environments and through preventive measures supporting health surveillance actions. The latter are already in progress in many countries, even though they are precariously implemented. In addition, so far there is only little data on the extent of this dangerous exposure [13].

Attention is given to health surveillance, encouragement and education for the use of appropriate Personal Protective Equipment (PPE), hygiene care and collective protection measures to reduce the risk of damages caused by benzene 
and other compounds that make up fuels used in Brazil. The use of PPE as a mandatory measure based on regulation NR-6 is within the responsibility of the employer who should inform the employees about risks of their work. This standard, however, does not present specific PPE for persons exposed to BTEX compounds. These PPE comprise face shields, shoes, pants, overalls, respirators, air purifiers and gloves [14].

A study carried out with gas station workers showed the correlation between the non-use of PPE workers and toluene intoxication by means of laboratory tests. According to these tests, the toxicity was verified in those workers who did not use the safety equipment, attesting a lack of knowledge by part of these workers, regarding the risks of occupational exposure [15].

In a previous study, the BTEX concentrations in the air of gas stations in Bahia were determined and the health risks of workers caused by exposure to these compounds were evaluated [3]. The objective of this study was to identify and analyze symptoms of occupational exposure to BTEX compounds found in workers at gas stations in the cities of Riachão do Jacuipe, Feira de Santana and Salvador in the state of Bahia, Brazil in respect to their occupational habits and the use of personal protective equipment.

\section{Material and Methods}

This is a descriptive exploratory quali-quantitative study based on data collected from workers at gas stations. The study was conducted between January and June 2016 in 13 gas stations in the cities of Riachão do Jacuípe, Feira de Santana and Salvador, located in the state of Bahia, Brazil.

The sample population consisted of 15 workers from gas stations in Riachão do Jacuipe, 45 in Feira de Santana and 53 in Salvador. The number individuals participants in the current study is equal to the amount of workers at gas stations in the same locations studied in a previous study about the determination the concentrations of BTEX compounds in the air and evaluation the health risks of workers [3].

These 113 workers, both males and females, were healthy, more than 18 years old, all of them having a minimum weekly workload of 30 hours regardless of the weekday were selected according to the following criteria: working directly with the fuel pump, consenting participate in study, and presenting more than 1 year in service in the evaluated activity.

The workers taking part in the study were informed about the purpose of the research, as well as about the privacy of the participants. They signed the Term of Free and Informed Consent (TFIC) in compliance with Resolution 466/2012 of the National Health Council [16]. The research instrument was applied with the authorization of the Brazilian Research Ethics Committee-CAAE$48,832,715.3 .0000 .5032$. Workers were interviewed during their normal work day by help of a questionnaire and their answers were used for data collection.

The interview was based on the following variables: characterization of the worker, such as sex, age, race, schooling, marital status and characteristics of 
their specific job such as function, working time in this function, working hours. The Statistical Package for the Social Sciences (SPSS) version 24 for Windows was used to analyze the data. Descriptive measures were presented for the variables and the Likelihood Ratio test was calculated to verify the association between the categorical variables and the level of statistical significance of $p<0.05$.

\section{Results and Discussion}

In contrast to what happens in most developed countries, in Brazil the self-service system at fuel stations is not usual so that it is possible to observe in a gas workers a wide variety of symptoms as a result of continuous exposure to compounds BTEX.

From a total of 113 interviewed workers, 79.2\% were male in Salvador while Feira de Santana and Riachão do Jacuipe presented values of $100 \%$ and $93.3 \%$, respectively. Regarding age, the workers were in the age range of 18 to 25 years $(30.08 \%)$ and 26 to 33 years $(34.51 \%)$ of the total sample in these three municipalities. Regarding health monitoring, $83.18 \%$ of the workers surveyed reported that they performed periodical exams every year.

In accordance with other publications most gas stations workers are young male adults [15] [17]. Physical strength is required to cope with the exhaustion due to the job. In addition, work at gas stations includes evident risks to health. Perhaps, this is why only few women decide to work at gas stations; the effects of exposure to the toxic organic compounds have led to the birth of underweight children and some studies also relate breast cancer to the carcinogenic and mutagenic potential of benzene [17] [18].

Concerning symptomatology, the most prevalent results were compatible with benzene exposure: headache, rhinitis, fatigue and cough proved the most frequent symptoms and complaints. Table 1 shows the various symptoms as reported in the 3 municipalities. A surprisingly high index of leg pain $(30.08 \%$; $24.4 \%$ and $46.7 \%$ respectively) was reported by workers in all 3 municipalities; whereas the incidence of myalgia (46.7\%) was reported only by the Riachão do Jacuipe workers.

All participants reported at least one of the described symptoms. Workers with fewer years of practice reported a greater number of symptoms. Workers with more years of practice presented an enhanced physiological adaptability to BTEX compounds. This shows that acute exposure is linked to more symptomatic complaints. On the other hand, chronic exposure to BTEX compounds provokes hematological changes with various clinical signs and symptoms [17] [19] [20].

The osteoarticular symptoms like leg pain and fatigue were most mentioned due to routine work, especially in Riachão do Jacuípe. Next, neurological, especially headache and respiratory symptoms-rhinitis were reported suggesting that both inhalation and skin contact with BTEX compounds can cause changes in those systems of the human body. These data are similar to those observed by Santiago and collaborators in a study carried out in Rio de Janeiro, Brazil [17]. 
Table 1. Prevalence of symptoms reported by workers at gas stations in cities of Salvador, Feira de Santana and Riachão do Jacuipe-BA, 2016.

\begin{tabular}{ccccccc}
\hline & \multicolumn{7}{c}{ CITIES } \\
\cline { 2 - 7 } SYMPTOMS & \multicolumn{2}{c}{$\begin{array}{c}\text { Salvador } \\
(\mathrm{n}=53)\end{array}$} & $\begin{array}{c}\text { Feira de Santana } \\
(\mathrm{n}=45)\end{array}$ & $\begin{array}{c}\text { Riachão do Jacuipe } \\
(\mathrm{n}=15)\end{array}$ \\
\cline { 2 - 8 } & \multicolumn{2}{c}{$\mathrm{n} \%$} & \multicolumn{2}{c}{$\mathrm{n} \%$} & \multicolumn{2}{c}{$\mathrm{n} \%$} \\
\hline Cough & 10 & 18.9 & 2 & 4.4 & 2 & 13.3 \\
Headache & 12 & $\mathbf{2 2 . 6}$ & 7 & 15.6 & 5 & 33.3 \\
Myalgia & 5 & 9.4 & 0 & 0.0 & 7 & 46.7 \\
Fatigue & 12 & $\mathbf{2 2 . 6}$ & 2 & 4.4 & 6 & 40.0 \\
Ocular hyperemia & 1 & 1.9 & 0 & 0.0 & 1 & 6.7 \\
Palpitations & 0 & 0.0 & 1 & 2.2 & 2 & 13.3 \\
Dyspnea & 3 & 5.7 & 0 & 0.0 & 2 & 13.3 \\
Tremors & 1 & 1.9 & 1 & 2.2 & 1 & 6.7 \\
Vertigo & 3 & 5.7 & 0 & 0.0 & 1 & 6.7 \\
Rhinitis & 12 & $\mathbf{2 2 . 6}$ & 4 & 8.9 & 4 & $\mathbf{2 6 . 7}$ \\
Insomnia & 5 & 9.4 & 2 & 4.4 & 1 & 6.7 \\
Dermatitis & 2 & 3.8 & 1 & 2.2 & 0 & 0.0 \\
Nausea & 0 & 0,0 & 0 & 0.0 & 1 & 6.7 \\
Leg pain & 16 & $\mathbf{3 0 . 2}$ & 11 & $\mathbf{2 4 . 4}$ & 7 & $\mathbf{4 6 . 7}$ \\
\hline
\end{tabular}

The BTEX compounds when inhaled attack the mucous membranes (eyes, nose, mouth, others) and can cause pulmonary edema (acute inflammation) and hemorrhage in airways. It also causes toxic effects to the central nervous system, which can lead to periods of drowsiness and excitement, dizziness, headache, nausea, tachycardia, respiratory distress, tremors, seizure, loss of consciousness and, finally, death [21]. Therefore, the respiratory tract is the most important route of absorption due to its large area, and it is more difficult to avoid inhaling the product that is dispersed in the air than to controlling its penetration via the skin or its ingestion [22]. Corroborating with our data, other studies have shown that workers at gas stations always complain of headache, allergic rhinitis, cough, tremors, vertigo, dyspnea, and especially myalgia and leg pain [8] [23] [24], the latter probably due to the same orthostatic position and absence of rest during the workday [8] [25].

Ocular changes are the first symptoms of exposure to hydrocarbons present in gasoline, which can lead to modifications in cornea and xerostomia. Such facts were observed in a study conducted to determine the occurrence of clinical changes due to exposure to BTEX compounds in gas station workers in Recife, Brazil. The same study discovered the predominance of ophthalmologic alterations, mainly ocular hyperemia among the workers [26]. The results obtained in the present study also showed ocular alterations.

The analysis of the data collected shows a positive correlation between several occupational habits of the workers which increase exposure to BTEX compounds and symptoms of intoxication. Obviously, the symptoms reported when associated with work habits increase both the intensity and the duration of ex- 
posure to these compounds.

Table 2 illustrates the occupational habits of gas station workers. It shows that $86.7 \%$ of them used the flannel to protect their hands when filling vehicles in Riachão do Jacuipe, followed by Feira de Santana workers (55.6\%) and only 3.9\% in Salvador. In Riachão do Jacuipe, the highest percentage was obtained with $33.3 \%$ of workers having the habit of smelling the cap before starting the filling in order to define in advance the type of fuel to be used.

Table 2 shows that $37.3 \%$ of workers in Salvador, $24.4 \%$ in Feira de Santana and $33.3 \%$ in Riachão do Jacuipe inhaled fuel from the tube while refueling the cars. On the other hand, $25.5 \%$ of workers in Salvador, $17.8 \%$ in Feira de Santana and $86.7 \%$ in Riachão do Jacuipe had a habit of put their own faces near the fuel tank to make sure it was full. In Salvador, $62.7 \%$ of the workers said they had had their clothes drenched with fuel during the working day, whereas $64.4 \%$ in Feira de Santana and $73.3 \%$ in Riachão do Jacuipe.

To avoid direct exposure to the fuel, workers must use the automatic nozzle to protect the worker from exposure to BTEX compounds. Only 3.54\% of them do not use the automatic nozzle, which contributes to increase the occurrence of occupational symptoms.

Table 3 shows that the PPE most used by workers in Salvador was boots (96.0\%), gloves (47.2\%) and goggles $47.2 \%$; in Feira de Santana it was boots (100\%), glasses (37.8\%) and gloves $(20.0 \%)$, and in Riachão do Jacuipe overalls (100\%), boots and glasses (73.3\%). The fact that different PPE were used by the same time, accounts for the percentage value above $100 \%$.

Table 2. Prevalence of habits that increase exposure to BTEX compounds reported by workers at gas stations in cities of Salvador, Feira de Santana and Riachão do Jacuipe-BA, 2016.

\begin{tabular}{|c|c|c|c|c|c|c|c|}
\hline \multirow{3}{*}{ Habits } & & \multicolumn{6}{|c|}{ Cities } \\
\hline & & \multicolumn{2}{|c|}{$\begin{array}{l}\text { Salvador } \\
(\mathrm{n}=53)\end{array}$} & \multicolumn{2}{|c|}{$\begin{array}{l}\text { Feira de Santana } \\
\qquad(\mathrm{n}=45)\end{array}$} & \multicolumn{2}{|c|}{$\begin{array}{l}\text { Riachão do Jacuipe } \\
\qquad(\mathrm{n}=15)\end{array}$} \\
\hline & & \multicolumn{2}{|c|}{$\mathrm{n} \%$} & \multicolumn{2}{|c|}{$\mathrm{n} \%$} & \multicolumn{2}{|c|}{$\mathrm{n} \%$} \\
\hline Uses flannel & Yes & 2 & 3.9 & 25 & 55.6 & 13 & 86.7 \\
\hline when filling & No & 49 & 96.1 & 20 & 44.4 & 2 & 13.3 \\
\hline $\begin{array}{l}\text { Smells the fuel } \\
\text { tank cap before }\end{array}$ & Yes & 3 & 5.9 & 3 & 6.7 & 5 & 33.3 \\
\hline starting to fill & No & 48 & 94.1 & 42 & 93.3 & 10 & 66.7 \\
\hline $\begin{array}{l}\text { Inspires fuel } \\
\text { from the gas }\end{array}$ & Yes & 19 & 37.3 & 11 & 24.4 & 5 & 33.3 \\
\hline $\operatorname{tank}$ & No & 32 & 62.7 & 34 & 75.6 & 10 & 66.7 \\
\hline $\begin{array}{l}\text { Puts his face } \\
\text { close to the }\end{array}$ & Yes & 13 & 25.5 & 8 & 17.8 & 13 & 86.7 \\
\hline tank & No & 38 & 74.5 & 37 & 82.2 & 2 & 13.3 \\
\hline Wet the clothes & Yes & 32 & 62.7 & 29 & 64.4 & 11 & 73.3 \\
\hline of fuel & No & 19 & 37.3 & 16 & 35.6 & 4 & 26.7 \\
\hline Uses automatic & Yes & 49 & 96.1 & 44 & 97.8 & 14 & 93.3 \\
\hline nozzle & No & 2 & 3.9 & 1 & 2.2 & 1 & 6.7 \\
\hline
\end{tabular}


Table 3. Prevalence of the use of PPE reported by workers at gas stations in cities of Salvador, Feira de Santana and Riachão de Jacuipe-BA, 2016.

\begin{tabular}{ccccccc}
\hline PPE & \multicolumn{9}{c}{ CITIES } \\
\cline { 2 - 7 } & \multicolumn{2}{c}{$\begin{array}{c}\text { Salvador } \\
(\mathrm{n}=53)\end{array}$} & $\begin{array}{c}\text { Feira de Santana } \\
(\mathrm{n}=45)\end{array}$ & $\begin{array}{c}\text { Riachão do Jacuipe } \\
(\mathrm{n}=15)\end{array}$ \\
\hline Overalls & $\mathrm{n}$ & $\%$ & $\mathrm{n}$ & $\%$ & $\mathrm{n}$ & $\%$ \\
Apron & 1 & 1.88 & 0 & 0.0 & 15 & 100 \\
Boots & 0 & 0.0 & 2 & 4.4 & 0 & 0.0 \\
Gloves & 51 & 96.0 & 45 & 100 & 13 & 86.7 \\
Mask & 25 & 47.2 & 9 & 20.0 & 2 & 13.3 \\
Goggles & 0 & 0.0 & 17 & 37.8 & 11 & 73.3 \\
\hline
\end{tabular}

The complaints about headache, cough and rhinitis reported by the workers in Salvador coincide with the lack of use of the mask of protection that avoids the inhalation of these compounds (Table 3). Just as the constant use of the flannel next to the body near the respiratory area by the workers of Riachão do Jacuipe can potentiate the exposure, since this is the same cloth used in the contact between the nozzle of the pump hose and the tank during filling. In this sense, even though most of the workers perform periodic examinations, their medical monitoring may not associate the cumulative effects of the exposure and, therefore, they cannot diagnose severe pathologies.

Regarding PPE, the use of boots was predominant, corroborating with other studies [23], while additional skin and inhalation protection equipment was reported only by some workers. Benzene and other organic compounds present in gasoline are absorbed when in contact with the skin and pass into the bloodstream; if a workman has a cutaneous lesion or wound the benzene absorption may be faster and may cause the same damages as occur by inhalation [27].

Although some of the workers responded that the gas stations owners distributed the necessary PPE for their protection, the proper use of this equipment by them was not notified. So, most workers seemed to regard the overalls offered to them as a means of protection (PPE) merely as a uniform. It is also worth noting that most workers identify only the uniform as PPE (Table 3). They worked with folded sleeves exposing their unprotected arms to contamination; this observation reveals the workers lack of concern or a lack of information regarding the risks of direct contact with fuels [28].

The relationship between the studied occupational habits and the symptoms reported by the workers interviewed can be seen in Tables 4-6.

Regarding the association of occupational habits with the symptoms of exposure to the BTEX compounds, the data obtained in Tables 4-6 show that the procedures reported by the attendants, such as using a piece of cloth when fueling vehicles, to inspire fuel, and to approach face of the vehicle tank as important when related to symptoms reported by these workers as headache, cough, fatigue, vertigo, palpitations, dyspnea and nausea. These observations suggest 
possible poisoning by BTEX via skin contact, by inhalation or oral intake.

Symptoms which are correlated with inhaled exposure habits were also reported in other studies, reinforcing that the respiratory pathway is the main route of benzene contamination [29] [30] [31]. Literature confirms that these symptoms result from the immediate effects of benzene exposure after direct contact with gasoline vapors inhaled or absorbed by workers at the time of vehicle supply [29].

Table 4. Association between the act of smelling the fuel tank cap prior to refueling and the symptoms of BTEX intoxication reported by workers at gas stations in Salvador, Feira de Santana and Riachão do Jacuipe-BA, 2016.

\begin{tabular}{|c|c|c|c|c|c|c|}
\hline \multirow{3}{*}{ Symptoms } & \multicolumn{6}{|c|}{ CITIES } \\
\hline & \multicolumn{2}{|c|}{$\begin{array}{l}\text { Salvador } \\
(\mathrm{n}=53)\end{array}$} & \multicolumn{2}{|c|}{$\begin{array}{l}\text { Feira de Santana } \\
\qquad(\mathrm{n}=45)\end{array}$} & \multicolumn{2}{|c|}{$\begin{array}{l}\text { Riachão do Jacuipe } \\
\qquad(\mathrm{n}=15)\end{array}$} \\
\hline & $\%$ & P-value & $\%$ & P-value & $\%$ & P-value \\
\hline Headache & 13.3 & 0.11 & - & - & 33.3 & 0.05 \\
\hline Fatigue & - & - & - & - & 33.3 & 0.02 \\
\hline Ocular hyperemia & 2.0 & 0.039 & - & - & - & - \\
\hline Mood change & 4.1 & 0.036 & - & - & - & - \\
\hline Mialgia & - & - & - & - & 26.7 & 0.02 \\
\hline
\end{tabular}

Table 5. Association between the habit of inhaling fuel during vehicle supply with the hose and symptoms of BTEX intoxication reported by gasoline workers in Salvador, Feira de Santana and Riachão do Jacuipe-BA, 2016.

\begin{tabular}{ccccccc}
\hline & \multicolumn{8}{c}{ CITIES } \\
\cline { 2 - 7 } Symptoms & \multicolumn{2}{c}{$\begin{array}{c}\text { Salvador } \\
(\mathrm{n}=53)\end{array}$} & $\begin{array}{c}\text { Feira de Santana } \\
(\mathrm{n}=45)\end{array}$ & $\begin{array}{c}\text { Riachão do Jacuipe } \\
(\mathrm{n}=15)\end{array}$ \\
\hline & $\%$ & P-value & $\%$ & P-value & $\%$ & P-value \\
\hline $\begin{array}{c}\text { Palpitations } \\
\text { Xerostomia }\end{array}$ & - & - & & & 33.3 & 0.03 \\
Fatigue & 2.0 & 0.13 & - & - & - & - \\
Cough & 3.9 & 0.17 & - & - & - & - \\
\hline
\end{tabular}

Table 6. Association between the habit of using piece of cloth when fueling the vehicle and symptoms of BTEX intoxication reported by workers at gas stations in Salvador, Feira de Santana and Riachão de Jacuipe-BA, 2016.

\begin{tabular}{|c|c|c|c|c|c|c|}
\hline \multirow{3}{*}{ Symptoms } & \multicolumn{6}{|c|}{ CITIES } \\
\hline & \multicolumn{2}{|c|}{$\begin{array}{l}\text { Salvador } \\
(\mathrm{n}=53)\end{array}$} & \multicolumn{2}{|c|}{$\begin{array}{l}\text { Feira de Santana } \\
\qquad(\mathrm{n}=45)\end{array}$} & \multicolumn{2}{|c|}{$\begin{array}{l}\text { Riachão do Jacuipe } \\
\qquad(\mathrm{n}=15)\end{array}$} \\
\hline & $\%$ & $\mathrm{P}$-value & $\%$ & $\mathrm{P}$-value & $\%$ & $\mathrm{P}$-value \\
\hline Headache & - & - & & & 33.3 & 0.05 \\
\hline Vertigo & - & - & - & - & 26.7 & 0.03 \\
\hline Nausea & - & - & - & - & 26.7 & 0.03 \\
\hline Ocular hyperemia & 2.0 & 0.03 & & & - & - \\
\hline
\end{tabular}


A study carried out at gas stations in Santa Catarina, Brazil, showed a strong statistical association between occupational habits and frequent symptoms reported by workers, such as dizziness, headache, xerostomia, irritation of the lower airways, dyspnea, bronchitis and palpitations resulting from inhalation of benzene. This study also shows that the most prevalent habits among the participants were the same ones reported in our work in the cities of Bahia.

The toxicity of benzene does not depend exclusively on the route of introduction into the body. However, inhalation of vapors is considered as the main route to intoxication, causing irritation of the ocular and respiratory mucosae. The dermal route is also of great importance for occupational exposure, which is influenced by skin temperature, its integrity and its hydration [32]. Thus, it is highly important to use personal protective equipment (PPE) suitable for gas station workers as a form of occupational exposure protection [9] [27].

The results indicate the immediate need to adopt measures to preventing or prohibiting such practices that increase exposure to BTEX compounds. The complaints about headache, cough and rhinitis reported by the workers in Salvador coincide with the lack of using masks of protection that avoids the inhalation of these toxic compounds. Just as the constant use of the flannel next to the body near the respiratory area by the workers of Riachão do Jacuipe can potentiate the exposure, since this is the same cloth used to contact the nozzle of the pump hose and the tank during filling. In this sense, even though most of the workers perform periodic examinations, their medical monitoring may not associate the cumulative effects of the exposure and, therefore, they cannot diagnose severe damages.

Considering that the etiological relationship depends on the degree, intensity and time of exposure to a toxic substance, a significant portion of the respondents do not consider the principles of biosafety regarding the prevention and minimization of health risks. The use of PPE by workers can minimize and prevent risks related to the BTEX compounds exposure [3].

\section{Conclusion}

This study showed that workers of gas stations are exposed to intoxication due to the contact with compounds BTEX mainly benzene which may cause harmful effects on health like headache, rhinitis, fatigue and cough symptoms. Toxicity occurs mainly through the respiratory tract, but may also occur via the skin. A strong correlation between occupational habits and intoxication symptoms to the compounds BTEX indicates the need for preventive measures such as environmental monitoring, individual hygiene care, and adequate use of PPE which means that these workers must use gloves, boots, masks and appropriated clothes to avoid the related risks, as well as professional safety training to avoid unnecessary exposure to toxic organic compounds. Most certainly PPE could contribute to preventing hazardous symptoms and diseases caused by daily exposure to BTEX compounds present in fossil fuels. 


\section{Acknowledgements}

The authors acknowledge to the FAPESB for fellowships. We are grateful to Ms

Elsbe Kraack for her tireless contribution technical assistance to this manuscript.

\section{References}

[1] Kumar, A. and Anand, S. (2012) Status of Vehicular Pollution in NCT of Delhi. International Journal of Advanced Research in Management and Social Sciences, 1 , 85-100.

[2] Dewulf, J., Langenhove, V.H. and Wittmann, G. (2002) Analysis of Volatile Organic Compounds Using Gas Chromatography. Trends in Analytical Chemistry, 21, 637646.

[3] Cruz, L.P.S., Alves, L.P., Santos, A.V.S., Esteves, M.B., Gomes, Í.V.S. and Nunes, L.S.S.(2017) Assessment of BTEX Concentrations in Air Ambient of Gas Stations Using Passive Sampling and the Health Risks for Workers, Journal of Environmental Protection, 8, 12-25. https://doi.org/10.4236/jep.2017.81002

[4] Snyder, R. (2012) Leukemia and Benzene. International Journal of Environmental Research and Public Health, 9, 2875-2893. https://doi.org/10.3390/ijerph9082875

[5] Jo, W.K. and Song, K.B. (2001) Exposure to Volatile Organic Compounds for Individuals with Occupations Associated with Potential Exposure to Motor Vehicle Exhaust and/or Gasoline Vapor Emissions. The Science of the Total Environment, 269, 25-37.

[6] Lee, C.C., Chen, M.R., Shih, T.S., Tsai, P.J., Lai, C.H. and Liou, S.H. (2002) Exposure Assessment on Volatile Organic Compound (VOCs) for Tollway Station Workers via Direct and Indirect Approaches. Journal Occupational Health, 44, 294300. https://doi.org/10.1539/joh.44.294

[7] International Agency for Research on Cancer (1987) Monographs on the Evaluation of Carcinogenic Risks to Humans. Overall Evaluations of Carcinogenicity, 1-42, Suppl 7.

[8] D’alascio, R.G., Menegali, M., Bornelli, A.S. and Magajewsk, F. (2014) Sintomas relacionados à exposição ocupacional ao benzeno e hábitos ocupacionais em trabalhadores de postos de revenda de combustíveis a varejo na região sul de Santa Catarina. Revista Brasileira de Medicina do Trabalho, 12, 1-9.

[9] Tunsaringkarn, T., Siriwong, W., Rungsiyothin, A. and Nopparatbundit, S. (2012) Occupational Exposure of Gasoline Station Workers to BTEX Compounds in Bangkok, Thailand. The International Journal of Occupational and Environmental Medicine, 3, 117-125.

[10] Tunsaringkarn, T., Zapuang, K. and Rungsiyothin, A. (2013) Correlation between Blood Cell Parameters and BTEX Exposure among Gasoline Station Workers. Journal of Environmental and Occupational Science, 2, 15-20. https://doi.org/10.5455/jeos.20130212090833

[11] Agency for Toxic Substances and Disease Registry (2004) Interaction Profile for: Benzene, Toluene, Ethylbenzene, and Xylenes (BTEX). Department of Public Health and Human Services, Atlanta.

[12] Instituto Nacional de Câncer (2012) As Diretrizes para a Vigilância do Câncer relacionado ao Trabalho, Rio de Janeiro.

http://www1.inca.gov.br/inca/Arquivos/comunicacao/diretrizes_cancer_trabalho.pd $\underline{\mathrm{f}}$

[13] World Health Organization (2004) Comparative Quantification of Health Risks: 
Global and Regional Burden of Disease Attributable to Selected Major Risk Factors. 1652-1801, Geneva.

[14] Ministério do trabalho (2015) NR 6-Equipamento de Proteção Individual-EPI. http://trabalho.gov.br/images/Documentos/SST/NR/NR6.pdf

[15] Grendele, G.L. and Teixeira, M.L. (2009) Avaliação de Ácido Hipúrico como Biomarcador de Exposição Ocupacional em Trabalhadores de Postos de Combustíveis. Revista Saúde e Pesquisa, 2, 319-324.

[16] Conselho Nacional de Saúde do Brasil (2012) Resolução no. 466. Brasília. http://www.conselho.saude.gov.br/resolucoes/2012/Reso466.pdf

[17] Santiago, F., Alves, G., Otero, U.B., Tabalipa, M.M., Scherrer, L.R., Kosyakova, N., Ornellas, M.H. and Liehr, T. (2014) Monitoring of Gas Station Attendants Exposure to Benzene, Toluene, Xylene (BTX) Using Three-Color Chromosome Painting. Molecular Cytogenetic, 7, 1-7. https://doi.org/10.1186/1755-8166-7-15

[18] Chen, D., Cho, S.I., Chen, C., Wang, X., Andrew, I.D., Louise, R., Thomas, J.S., David, C.C. and Xiping, X. (2000) Exposure to Benzene, Occupational Stress, and Reduced Birth Weight. Occupational and Environmental Medicine, 57, 661-667. https://doi.org/10.1136/oem.57.10.661

[19] Arnold, S.M., Angerer, J., Boogaard, P.J., Hughes, M.F., O’Lone, R.B., Robison, S.H. and Schnatter, A.R. (2013) The Use of Biomonitoring Data in Exposure and Human Health Risk Assessment: Benzene Case Study. Critical Reviews in Toxicology, 43, 119-153. www.tandfonline.com/doi/full/10.3109/10408444.2012.756455 https://doi.org/10.3109/10408444.2012.756455

[20] Bolden, A.L., Kwiatkowski, C.F. and Colborn, T. (2015) New Look at BTEX: Are Ambient Levels a Problem? Environmental Science \& Technology, 49, 5261-5276. https://doi.org/10.1021/es505316f

[21] Arcuri, A.S.A., Costa, D.F., Possebon, J., Kanasawa, K.C., Tardini, L.I.N., Constantino, L., Costa, L.M.T., Cardoso, L.M.N., Gelber, M.A., Yassuda, N. and Inamine, R. (2012) Efeitos da exposiçãoaobenzeno para a saúde. São Paulo. Available in: http://ie.org.br/site/ieadm/arquivos/arqnot9145.pdf

[22] Smith, M.T. (2010) Advances in Understanding Benzene Heath Effects and Susceptibility. Annual Review of Public Health, 31, 133-148. https://doi.org/10.1146/annurev.publhealth.012809.103646

[23] Sairat, T., Homwuttiwong, S., Homwutthiwong, K. and Ongwandee, M. (2015) Investigation of Gasoline Distributions within Petrol Stations: Spatial and Seasonal Concentrations, Sources, Mitigation Measures, and Occupationally Exposed Symptoms. Environmental Science and Pollution Research, 22, 13870-13880. https://doi.org/10.1007/s11356-015-4615-3

[24] Ruiz, M.A., Vassallo, J. and Souza, C.A. (2013) Alterações Hematológicas em Pacientes Expostos Cronicamente ao Benzeno. Revista Saúde Pública, 27, 145-151. https://doi.org/10.1590/S0034-89101993000200011

[25] Ruiz, M.A., Augusto, L.G.S., Vassllo, J., Vigorito, A.C., Lorand-Metze, I. and Souza, C.A. (1994) Bone Marrow Morphology in Patients with Neutropenia due to Chronic Exposure to Organic Solvents (Benzene): Early Lesions. Pathology Research and Practice, 190, 151-154.

[26] Hinrichsen, S.L.,Cavalcanti, R., Jucá, M.B., Albuquerque, S.M.C., Silva, B., Godoi, J., Lopes, E., Ribeiro, A., Reinaldo, R.E., Lima, I.G.S., Carneiro, A.F., Cardoso, G.S.A. and Figueira, J.N. (2003) Alterações clínicas e oftalmológicas em frentistas expostos a vapores de derivados de petróleo em postos de gasolina do Grande Recife. Revista Brasileira de Medicina, 61, 529-538. 
[27] Cezar-vaz, M.R., Rocha, L.P., Bonow, C.A., Silva, M.R.S., Vaz, J.C. and Cardoso, L.S. (2012) Risk Perception and Occupational Accidents: A Study of Gas Station Workers in Southern Brazil. International Journal of Environmental Research and Public Health, 9, 2362-2377. https://doi.org/10.3390/ijerph9072362

[28] Periago, J.F. and Prado, C. (2005) Evolution of Occupational Exposure to Environmental Levels of Aromatic Hydrocarbons in Service Stations. Annals of Occupational Hygiene, 49, 233-240.

[29] Macfarland, H.N., Ulrich, C.E. and Holdsworth, C.E. (1984) A Chronic Inhalation Study with Unleaded Gasoline Vapor. Journal of America College of Toxicology, 3, 231-248.

[30] Gordian, M.E., Stewart, A.W. and Morris, S.S. (2010) Evaporative Gasoline Emissions and Athma Symptoms. International Journal of Environmental Research and Public Health, 7, 3051-3062. https://doi.org/10.3390/ijerph7083051

[31] Scheepers, P.T. and Bos, R.P. (1992) Combustion of Diesel Fuel from a Toxicological Perspective. International Archives of Occupational and Environmental Health, 64, 163-167.

[32] Ministério da Saúde do Brasil (2001) Doenças relacionadas ao Trabalho. Manual de Procedimentos para os Serviços de Saúde, série A. Normas e Manuais Técnicos, no. 114, Brasília.

Submit or recommend next manuscript to SCIRP and we will provide best service for you:

Accepting pre-submission inquiries through Email, Facebook, LinkedIn, Twitter, etc. A wide selection of journals (inclusive of 9 subjects, more than 200 journals)

Providing 24-hour high-quality service

User-friendly online submission system

Fair and swift peer-review system

Efficient typesetting and proofreading procedure

Display of the result of downloads and visits, as well as the number of cited articles

Maximum dissemination of your research work

Submit your manuscript at: http://papersubmission.scirp.org/

Or contact jep@scirp.org 